\title{
Intestinal Glucose Transport in Suckling Rats Fed Artificial Milk with and without Added Epidermal Growth Factor
}

\author{
HARRY L. GREENE, MARY C. MOORE, HAMID M. SAID, FAYEZ K. GHISHAN, AND \\ DAVID N. ORTH \\ Vanderbilt University School of Medicine, Clinical Nutrition Research Unit Laboratory, Medical Center North, \\ Nashville, Tennessee 37232
}

\begin{abstract}
Edpidermal growth factor (EGF), a potent mitogen present in milk, is postulated to play an important physiologic role in the ontogeny of the intestine. An artificial rat milk, free of EGF, was developed and fed to newborn rats in an effort to evaluate the physiologic role of EGF on intestinal glucose transport. Comparisons were made between mother-fed (group 1) and artificially fed pups (group 2). Group 1 was divided into two subgroups to receive either the EGF vehicle (group 1-A) or twice daily subcutaneous injections $(0.1 \mu \mathrm{g} / \mathrm{g}$ body weight/day) of EGF (group 1-B). Group 2 was divided into four subgroups: formula without EGF (group 2-A), formula with $62 \mathrm{ng} / \mathrm{ml}$ of EGF (group 2-B), formula with $200 \mathrm{ng} / \mathrm{ml} \mathrm{EGF} \mathrm{(group}$ 2-C), and formula without EGF but added anti-EGF IgG $(40 \mathrm{ng} / \mathrm{ml})$ plus subcutaneous injections of $1 \mu \mathrm{g}$ anti-EGF twice daily (group 2-D). Treatment regimens were initiated on day 3 and assays performed on day 11 of life. Glucose transport was measured using gut "sheet" preparations in all but group 2-C, which utilized brush border membrane preparations. Group 1-B showed a significant $(p<0.03)$ increase in gut length $(47.5 \pm 1.2$ versus $42 \pm 0.9 \mathrm{~cm})$ and an increase $(p<0.03)$ in both $V_{\max }(10.2 \pm 0.5$ versus 7.2 $\pm 0.3 \mathrm{nM} / \mathrm{mg}$ tissue $)$ and $K_{m}(2.74 \pm 0.49$ versus $1.20 \pm$ $0.19 \mathrm{mM}$ ) compared to group 1-A. All pups in group 2 showed a significant $(p<0.03)$ increase in intestinal length compared to group 1-A, but no difference was seen between group 1-B and all subsets of group 2. Glucose uptake was similarly affected with the exception that only the $V_{\max }$ was significantly increased by tube feeding. The suggested increase in glucose carriers resulting from EGF was further supported by the finding that only the large oral or systemic dose of EGF (groups 1-B and 2-C) caused a significant ( $p$ $<0.01$ ) increase in the 1-minute accumulation ("overshoot") of glucose in the brush border membrane. Whereas pharmacologic doses of EGF caused premature development of intestinal glucose transport and increased gut length, artificial feeding alone caused a similar increase in intestinal length and $\mathbf{V}_{\max }$ for glucose transport. (Pediatr Res 21: 404-408, 1987)
\end{abstract}

\section{Abbreviations}

EGF, epidermal growth factor

BBMV, brush border membrane vesicles ANOVA, analysis of variance

Received September 25, 1986; accepted December 2, 1986

Author to whom all correspondence and reprint requests should be sent Harry L. Greene, M.D., Department of Pediatrics, Division of Gastroenterology and Nutrition, Vanderbilt University School of Medicine, D-4130, Medical Center North, Nashville, TN 37232.

Supported by NIH NIADDKD AM 26657-05, Mead Johnson Nutrition Division, and Sandoz Nutrition.
EGF is a potent mitogen for a variety of cells in vivo and in vitro $(1,2)$. Recent reports have shown that EGF is a trophic substance for gastrointestinal mucosa that promotes maturation of absorptive cells in duodenal explants (3) as well as enhances activities of several intestinal hydrolytic enzymes (4) and net calcium transport in suckling and weanling animals (5). The presence of EGF in high concentrations in human $(6,7)$ and rat milk, its resistance to acid $(1,9)$ and pancreatic enzyme hydrolysis (10), and the presence of high affinity receptors for EGF in the small intestine (8) led us to postulate that EGF in maternal milk plays an important physiologic role in the ontogeny of the intestine.

To date, most studies evaluating the effects of EGF on the intestine have used pharmacologic doses of EGF in suckling pups consuming maternal milk. In an effort to evaluate the hypothesized physiologic effects of EGF on developing rat intestine, we developed an EGF deficient, artificial formula which could provide somatic growth similar to that of suckling animals $(11,12)$. Therein we describe our findings on glucose transport in pups fed the artificial formula with EGF and without EGF as well as anti EGF IgG. Results were also compared to control suckling pups, and suckling pups given twice daily subcutaneous injections of EGF from days 3-10 of life.

\section{METHODS}

Animal model. Sprague-Dawley rat pups were allowed to nurse for 3 days after birth. We had noted previously (13) that rat milk EGF levels were $8 \pm 2 \mathrm{ng} / \mathrm{ml}$ or less up to 4 days of lactation followed by a progressive increase to $38 \pm 7$ and $51 \pm 9 \mathrm{ng} / \mathrm{ml}$ by 8 and 11 days of lactation, respectively. The pups were weighed and randomly assigned by paired weights to one of two groups: 1) a normally reared group remaining with lactating females in litters of eight to nine pups or 2) an artificially reared group receiving intragastric tube feedings. The first group was divided into subgroups of eight to nine pups each. Subgroup 1$\mathrm{B}$ was given subcutaneous injections of EGF $(0.1 \mu \mathrm{g} / \mathrm{g}$ body weight) twice daily and subgroup 1-A was given an equal volume of EGF vehicle twice daily. The second group was divided into four subgroups of six to eight pups each that received either (subgroup 2-A) an artificial formula without EGF, (subgroup 2B) a physiologic dose $(62 \pm 6 \mathrm{ng} / \mathrm{ml})$ of EGF added to the formula, (subgroup 2-C) a pharmacologic dose $(200 \mathrm{ng} / \mathrm{ml})$ of EGF added to the formula, or (subgroup 2-D) no EGF but with, anti EGF IgG fraction $(40 \mathrm{ng} / \mathrm{ml})$ added to the formula, plus a subcutaneous injection of anti-EGF IgG $1 \mu \mathrm{g}$ twice daily. Only 24 pups could be artificially fed at one time. Therefore, in order to make simultaneous comparisons, experiments were repeated with the control groups (groups 1-A, 1-B, and 2-A) on both occasions. The number of data points in these groups are therefore twice the number in each of the other groups.

The formula without added EGF had an undetectable level of EFG. On day 11 of life ( 8 days of treatment), all rats were sacrificed and intestinal transport was studied. 
Artificial formula. Development of the artificial formula for tube feeding was derived from published data on rat milk composition $(11,12)$. Each $100 \mathrm{ml}$ contained $159 \mathrm{kcal}, 9.1 \mathrm{~g}$ protein, $3.5 \mathrm{~g}$ carbohydrate ( $2.2 \mathrm{~g}$ lactose and $1.3 \mathrm{~g}$ maltodextrins), and $12.03 \mathrm{~g}$ fat with minerals and vitamins approximating that present in rat milk (11). The osmolality of the formula was 457 mosmol/ $\mathrm{kg}$ by the freezing point method and $452 \mathrm{mosmol} / \mathrm{kg}$ by the vapor pressure method. The formula was prepared daily from powderded constituents. Details of the formula content and preparation are presented elsewhere (13). No more than a 12-h supply was placed in syringes for infusion at any one time. Pups were weighed daily, and the infusion rate was adjusted according to the rate of weight gain.

Tube feeding. Tube feeding was delivered through a silicone rubber catheter (Silastic, Dow Corning Corp, Midland, MI) with an internal diameter of $0.305 \mathrm{~mm}$ and an external diameter of $0.635 \mathrm{~mm}$. The catheter was gently inserted into the stomach through the mouth and secured to the lip and head with cyanoacrylate glue which had been found not to alter normal pup growth when applied to the back of suckling pups. The pups were housed in individual styrofoam cups and floated in a water bath $\left(37-40^{\circ}\right.$ C). The anogenital area was stroked every 3-4 h to stimulate voiding and defecation. Wood chips in the cups were changed daily. The formula was infused continuously by attaching the tubing to a syringe mounted on an infusion pump (Harvard Apparatus, Model 2265, South Natick, MA). Each pup received approximately $0.5 \mathrm{kcal} / \mathrm{g}$ body weight/day (14). We had previously shown that adult glucose transport kinetics are reached by day 13-15 (25). Thus, to determine precocious development caused by EGF, pups were sacrificed on day 11. On day 11 of life (after 8 days of tube-feeding) the pups were killed, and intestinal glucose transport was determined.

Preparation of EGF. Mouse EGF was prepared from male mouse submandibular glands by the method of Savage and Cohen (15). It had full biologic activity, as assessed by radioreceptor assay (16) and stimulation of ${ }^{3} \mathrm{H}$-thymidine uptake by cultured human foreskin fibroblasts (17) as previously reported (18).

Submandibular glands were removed from adult male rats, and EGF was extracted and subjected to acidic Bio-Gel P10 (BioRad Laboratories, Richmond, CA) chromatography (9). Rat EGF, as monitored by radioreceptor activity (16), was retarded on this column, but not to the extent of mouse EGF (9). Active fractions were pooled, lyophilized, and reapplied to the same column, reequilibrated and developed with $0.1 \mathrm{M} \mathrm{NaCl}, 0.02 \mathrm{M}$ sodium phosphate buffer, $\mathrm{pH}$ 6.2. Active fractions were pooled and subjected to reverse phase high-performance liquid chromatography on a $\mathrm{C}_{18}$ column (Supelco, Bellefonte, PA) in a trifluoracetic acid-acetonitrile solvent system (22). The complete amino acid sequence was determined after reduction, carboxymethylation and cyanogen bromide cleavage, and the C-terminal sequence was confirmed using carboxypeptidase $\mathrm{Y}$ digestion (Mount CD, Lukas TJ, Orth DN, unpublished data). As reported by Simpson et al. (19), rat EGF is a mixture of the 1-48, 2-48, and 3-48 peptides lacking the five C-terminal residues of mouse or human EGF.

Preparation of anti-EGF globulin. For the neutralization experiments, antibodies to EGF were raised in rabbits by injecting $10 \mu \mathrm{g}$ purified mouse EGF emulsified in $1 \mathrm{ml}$ complete Freund's adjuvant in multiple intradermal sites (20). Twelve high titer antisera were tested for their ability to bind rat EGF (a mixture of 1-48, 2-48, and 3-48 rat EGF which were not readily separable) in standard EGF radioimmunoassay $(21,22)$. They were first tested for their ability to bind trace quantities of ${ }^{125}$ I-labeled rat EGF. Three antisera that bound appreciable amounts of labeled rat EGF were further characterized by comparing the ability of unlabeled rat and mouse EGF to compete with ${ }^{125} \mathrm{I}$-labeled rat EGF tracer for antibody binding sites. One antiserum, R14, had the requisite titer, binding affinity, and total volume for these studies.

The anti-EGF IgG in antiserum R14 was purified by affinity chromatography Mouse. EGF was coupled to Sepharose CL-6B (Pharmacia Fine Chemicals, Piscataway, NJ) by a modification of the method of Cuatrecasas (23). One $\mathrm{g}$ of cyanogen bromide was added to $10 \mathrm{ml}$ packed volume of Sepharose CL-6B in 20 $\mathrm{ml}$ water. The $\mathrm{pH}$ was raised above 11 and maintained until the reaction was complete, as indicated by no further liberation of acid. The temperature of the reaction mixture was maintained less than $20^{\circ} \mathrm{C}$ by adding small amounts of ice. After the reaction was complete, the mixture was diluted with $20 \mathrm{~g}$ of ice, and the gel was washed on a filter with $100 \mathrm{ml}$ ice-cold coupling buffer $\left(0.5 \mathrm{M} \mathrm{NaCl}, 0.1 \mathrm{M} \mathrm{NaHCO}_{3}, \mathrm{pH} 8.5\right)$. Mouse EGF, $1 \mathrm{mg}$ dissolved in $1 \mathrm{ml} 10 \mathrm{mM} \mathrm{HCl}$, was diluted with $1 \mathrm{ml}$ coupling buffer, added to $1 \mathrm{ml}$ packed volume of cyanogen bromideactivated Sepharose CL-6B suspended in $2 \mathrm{ml}$ coupling buffer, and mixed slowly end-over-end at room temperature overnight. The gel was then packed into a small column and washed successively with 50 -ml volumes of $0.5 \mathrm{M} \mathrm{NaCl} ; 0.5 \mathrm{M} \mathrm{NaCl}$, $2 \%$ acetic acid; $0.5 \mathrm{M} \mathrm{NaCl} ; 0.5 \mathrm{M} \mathrm{NaCl}, 0.1 \mathrm{M}$ Tris- $\mathrm{HCl}, \mathrm{pH}$ 8.5 ; and radioimmunoassay buffer $\left(63 \mathrm{mM} \mathrm{Na}_{2} \mathrm{HPO}_{4}, 13 \mathrm{mM}\right.$ disodium EDTA, $3 \mathrm{mM} \mathrm{NaN}_{3}$, and $0.1 \%$ Triton $\times-100$ ). The binding of mouse EGF to the activated gel, as measured by disappearance of absorbance at $280 \mathrm{~nm}$ from the coupling solution, was $84 \%$.

Twenty-five $\mathrm{ml}$ of antiserum R14 were added to the mouse EGF-Sepharose and incubated with gentle end-over-end mixing for $2 \mathrm{~h}$ at room temperature. The gel was allowed to settle briefly, most of the supernate was aspirated, and the gel was packed into a small column and washed with $50 \mathrm{ml}$ phosphate-buffered saline followed by $10 \mathrm{ml}$ saline. The column outlet was clamped, $2 \mathrm{ml}$ Sorenson's glycine buffer $(0.1 \mathrm{M}$ glycine, $0.1 \mathrm{M} \mathrm{NaCl}$, titrated to pH 2.5 with $0.1 \mathrm{M} \mathrm{HCl}$ ) was added, the column top was stoppered, and the gel was suspended in the buffer by gentle endover-end mixing for $30 \mathrm{~min}$ at room temperature. The eluting buffer was drained from the column, which was washed with 3 $\mathrm{ml}$ of the same buffer. The combined eluate and wash was neutralized with $1 \mathrm{M} \mathrm{NaOH}$. The amount of $\mathrm{IgG}$ recovered was estimated by absorbance at $280 \mathrm{~nm}$, and its capacity for binding rat EGF was assessed by radioimmunoassay. The purification of anti-rat EGF IgG was approximately 160 -fold, and $1 \mu \mathrm{g}$ of the affinity-purified IgG was capable of binding at least $7.5 \mathrm{ng}$ of rat EGF.

Measurements. Preliminary studies to develop the formula and method of tube feedings indicated that for at least 8 days weight gain with tube feeding was comparable to the weight gain in maternally fed pups. For this reason studies were begun on day 3 and continued until day 11 . Animals were sacrificed by intracranial injections of $10 \%$ formalin, and the intestine was removed immediately, measured, and assayed for glucose transport characteristics.

Urine was collected by gently stroking the genital area and collection into $100 \mu \mathrm{l}$ capillary tubes. Since no EGF is lost with storage, urine samples were kept frozen at $-20^{\circ} \mathrm{C}$ and assayed simultaneously at the completion of the study.

Intestinal glucose transport. Because the intestines of pups less than 15 days of age are so friable, it was not possible to prepare everted gut sacs without sometimes severely damaging the villi. For this reason, the method of Batt and Schachter (24) was validated and used (25). The jejunum $(12 \mathrm{~cm}$ of the small intestine distal to the first $8 \mathrm{~cm}$ of the small intestine) was used for the glucose kinetic studies. The bowel was removed and washed with ice-cold Krebs-Ringer phosphate buffer, opened along its mesenteric side, and cut into $10-12$ pieces $1 \mathrm{~cm}$ long, excluding segments with visible lymph follicles. The intestinal sheets were kept in ice-cold continuously oxygenated $\left(100 \% \mathrm{O}_{2}\right)$ Krebs-Ringer phosphate buffer until incubation. They were then incubated in 25-ml Ehrlenmeyer flasks (four sheets per flask) containing $15 \mathrm{ml}$ of continuously oxygenated Krebs-Ringer phosphate buffer, pH $6.5\left(20 \mathrm{mM} \mathrm{NaH} \mathrm{PO}_{4}, 125 \mathrm{mM} \mathrm{NaCl}\right.$, $4.93 \mathrm{mM} \mathrm{KCl}^{1} 1.23 \mathrm{mM} \mathrm{MgSO}_{4}$, and $0.85 \mathrm{mM} \mathrm{CaCl}_{2}$ ). Unlabeled D-glucose, tracer amounts of $\mathrm{D}-\left[1^{-14} \mathrm{C}\right]$-glucose (specific activity $53.4 \mathrm{mCi} / \mathrm{mmol}$; New England Nuclear, Boston, MA), 
and $\mathrm{L}-\left[1-{ }^{3} \mathrm{H}(\mathrm{N})\right]$-glucose (specific activity $10.7 \mathrm{Ci} / \mathrm{mmol}$; New England Nuclear) were added to the incubation medium prior to incubation. L-Glucose was added to correct for fluid adherence and passive diffusion uptake of D-glucose (26). Incubation was performed in a shaking water bath (160 oscillation $/ \mathrm{min}$ ) at $0^{\circ} \mathrm{C}$ with continuous bubbling $100 \%$ oxygen. Continuous water bath shaking and oxygen bubbling minimized the unstirred water layer effect on D-glucose transport kinetic parameters and maximum oxygenation. At the end of incubation, individual intestinal sheets were removed, washed for $10 \mathrm{~s}$ with ice-cold buffer, blotted gently on filter paper, weighed, and placed in scintillation vials containing $0.2 \mathrm{ml}$ of $1 \mathrm{M} \mathrm{NaOH}$. The vials were incubated in an oven $\left(90^{\circ} \mathrm{C}\right)$ for $2 \mathrm{~h}$ to digest the intestinal tissue and allowed to cool at room temperature, and $0.2 \mathrm{ml}$ of $1 \mathrm{M} \mathrm{HCl}$ was added. Six ml of scintillation fluid (ACS, Amersham, Arlington Heights, IL) was added, and ${ }^{14} \mathrm{C}$ - and ${ }^{3} \mathrm{H}$-radioactivity was determined by double isotope counting and calculation technique (27).

To minimize the effect of variation between intestinal sheets from the same rat, two rats were killed simultaneously and intestinal sheets from both were mixed together in ice-cold phosphate buffer. Four sheets were randomly selected for incubation at each D-glucose concentration. The amount of D-glucose transported by the active mechanism was calculated (25) from the following formula:

$$
\mathrm{J}=\frac{{ }^{3} \mathrm{H}_{\mathrm{st}} \cdot{ }^{14} \mathrm{C}_{\mathrm{t}}-{ }^{14} \mathrm{C}_{\mathrm{st}} \cdot{ }^{3} \mathrm{H}_{\mathrm{t}}}{{ }^{3} \mathrm{H}_{\mathrm{st}} \cdot \mathrm{S} \cdot \mathrm{W}}
$$

where $\mathrm{J}$ represents the amount (nmol/mg tissue wet weight/unit time) of D-glucose transported by the active mechanism; ${ }^{14} \mathrm{C}_{\mathrm{st}}$ and ${ }^{3} \mathrm{H}_{\mathrm{st}}$ represent, respectively, the corrected $\mathrm{cpm}$ for $\mathrm{D}^{14} \mathrm{C}$ glucose and $\mathrm{L}-{ }^{3} \mathrm{H}$-glucose in the incubation buffer at time zero; ${ }^{14} \mathrm{C}_{\mathrm{t}}$ and ${ }^{3} \mathrm{H}_{\mathrm{t}}$ represent, respectively, the corrected cpm for $\mathrm{D}-{ }^{14} \mathrm{C}$ glucose and $\mathrm{I}-{ }^{3} \mathrm{H}$-glucose transported into the intestinal tissue at time $t ; S$ represents the specific activity of $D-{ }^{14} \mathrm{C}$-glucose at each concentration; and $\mathrm{W}$ represents the wet weight of the intestinal tissue in $\mathrm{mg}$.

BBMV transport studies. BBMV were prepared from jejunal segments of the rats using a modified divalent cation precipitation technique (28). Briefly, mucosal scrapings were homogenized and BBMV were precipitated with $0.1 \mathrm{M} \mathrm{MgCl}_{2}$ and isolated by differential centrifugation. We have previously demonstrated the purity of the BBMV preparation for rats of varying ages (28). D-Glucose transport was studied by a rapid filtration technique $(28,29)$. D-Glucose transport was studied in the presence of inwardly directed $\mathrm{Na}^{+}$and choline gradients.

Statistical analysis. Kinetic parameters $\left(\mathrm{k}_{\mathrm{m}}\right.$ and $\left.\mathrm{V}_{\max }\right)$ of the saturable active transport system of D-glucose were calculated from direct fits of Michaelis-Menten plots (30). Differences were determined by paired Student's $t$ tests between groups selected by the results of ANOVA.

\section{RESULTS}

Gut length. Table 1 summarizes the differences in small intestinal length (between the pyloric and ileocecal junction) among the two groups of mother-fed and the three groups of artificially fed rat pups. EGF treatment of the mother-fed pups resulted in a significant increase in gut length. All the pups that were fed artificially showed increases similar to those seen in the EGFtreated mother-fed pups and there were no differences between any of the groups of artificially fed pups. It was not possible to weigh the intestines because the time required to flush them of retained milk and weigh them accurately would have compromised their viability for transport studies. Somatic growth and organ weights are detailed in a previous publication (13). Body weights $(\mathrm{g})$ at sacrifice are as follows: group $1-\mathrm{A}=24 \pm 0.7$; group $1-\mathrm{B}=20 \pm 0.9(p<0.05)$; group $2-\mathrm{A}=21 \pm 0.2$; group $2-\mathrm{B}(62 \mathrm{ng} / \mathrm{mg})=20 \pm 0.8 ;$ group $2-\mathrm{C}(200 \mathrm{ng} / \mathrm{ml})=21 \pm 0.3$; group $2-\mathrm{D}=22 \pm 0.3$ (all group 2 pups were significantly less than group 1-A, but unchanged from group 1-B pups).

Urinary excretion of EGF increased from $4-6 \mathrm{ng} / \mathrm{ml}$ on day 4 to $38-51 \mathrm{ng} / \mathrm{ml}$ by day 10 . This 6 - to 8 -fold increase was seen in all groups of pups as depicted in Table 2. The tendency for EGF excretion to be higher in the mother-fed than the tube-fed pups was not statistically significant.

Table 2. Urinary EGF levels during treatment (mean $\pm S E M$, $n=6-8$ pups)*

\begin{tabular}{crrrr}
\hline Age (days) & Group 1-A & Group 2-A & Group 2-B & Group 2-D \\
\hline 4 & $4.8 \pm 0.9$ & $6.4 \pm 0.6$ & $5.7 \pm 0.8$ & $5.0 \pm 0.5$ \\
5 & $6.8 \pm 0.6$ & $7.3 \pm 1.1$ & $8.7 \pm 0.9$ & \\
6 & $12.5 \pm 3.4$ & $11.9 \pm 2.5$ & $10.0 \pm 1.9$ & $9.9 \pm 2.4$ \\
7 & $16.7 \pm 4.1$ & $14.4 \pm 3.0$ & $12.6 \pm 3.0$ & $13.9 \pm 3.0$ \\
9 & $41.0 \pm 6.6$ & $38.3 \pm 7.1$ & $43.6 \pm 9.4$ & $36.7 \pm 6.2$ \\
10 & $51.6 \pm 5.1$ & $39.5 \pm 8.1$ & $47.4 \pm 6.2$ & $38.3 \pm 7.4$ \\
11 & $63.5 \pm 6.4$ & & &
\end{tabular}

* Group 2-A = tube with EGF; group 2-B = tube fed $+62 \mathrm{ng} / \mathrm{ml}$ of EGF; group 2-D = tube fed + antibody injections and in formula; group $1-\mathrm{A}=$ mother fed without added EGF.

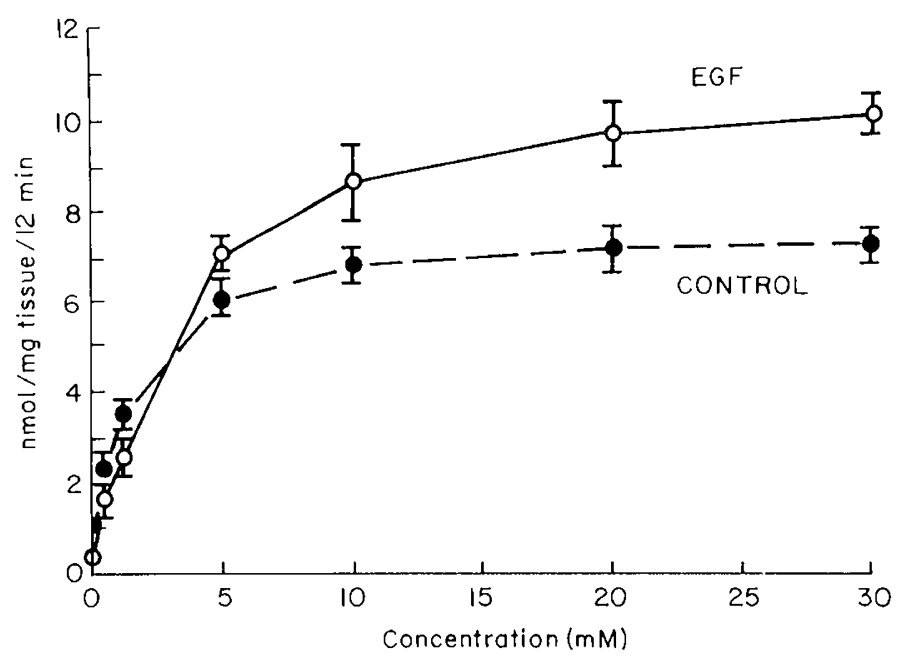

Fig. 1. Changes in the active component of glucose uptake at different glucose concentrations at $12-\mathrm{min}$ incubation. Comparisons are made between mother-fed pups in group 1-A (control) and groups $1-\mathrm{B}(0.1 \mu \mathrm{g}$ EGF/g body weight/day). There were significant differences between the points after 2 min of incubation as reflected in the transport kinetics for both $\mathrm{K}_{\mathrm{m}}$ and $\mathrm{V}_{\max }$ (see Table 1).

Table 1. Gut length and glucose transport kinetics (mean \pm SEM)

\begin{tabular}{lllr}
\multicolumn{1}{c}{ Group } & Length $(\mathrm{cm})$ & \multicolumn{1}{c}{$\mathrm{K}_{\mathrm{m}}(\mathrm{mM})$} & $\mathrm{V}_{\max }(\mathrm{nM} / \mathrm{mg}$ tissue $)$ \\
\hline 1-A mother-fed & $42.0 \pm 0.9^{*}$ & $1.20 \pm 0.19$ & $7.24 \pm 0.31$ \\
1-B mother fed + EGF & $47.5 \pm 1.6$ & $2.74 \pm 0.49^{*}$ & $10.20 \pm 0.50 \dagger$ \\
2-A Tube fed & $47.3 \pm 1.7$ & $1.41 \pm 0.26$ & $9.91 \pm 0.52 \dagger$ \\
2-B Tube fed + EGF $(65 \mathrm{ng} / \mathrm{ml})$ & $48.4 \pm 2.0$ & $1.52 \pm 0.21$ & $10.92 \pm 0.47 \dagger$ \\
2-D Tube fed + anti-EGF & $47.3 \pm 1.6$ & $1.33 \pm 0.24$ & $9.94 \pm 0.56 \dagger$ \\
\hline
\end{tabular}

* Different from all groups $(p<0.03)$.

$\dagger$ Different from group 1-A $(p<0.02)$. 


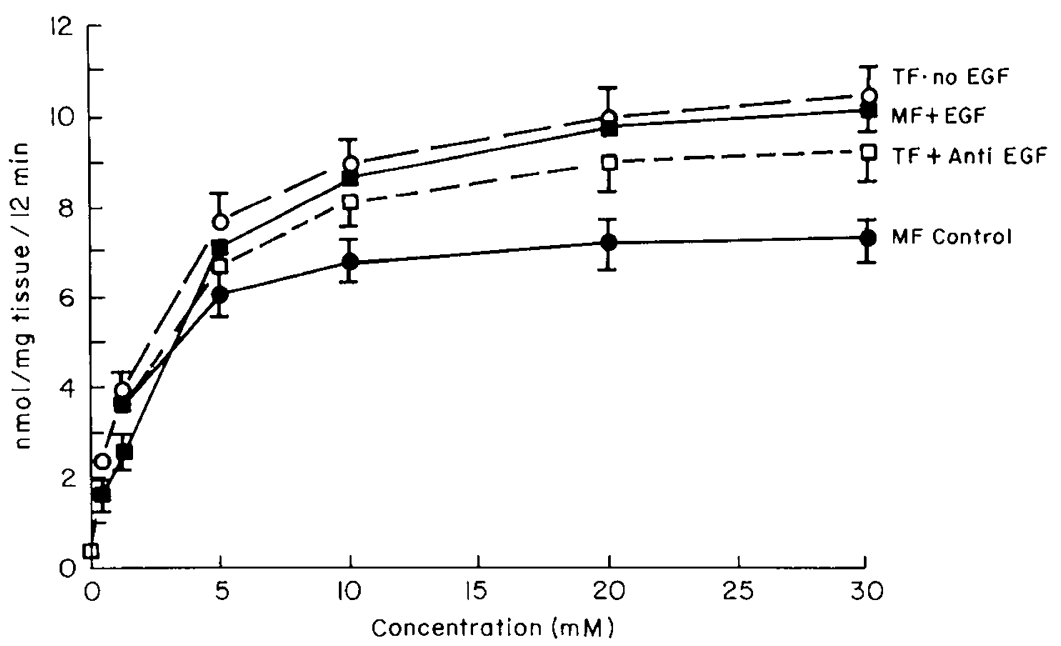

Fig. 2. Changes in the active component of glucose uptake at different concentrations of glucose in the incubation media. Graph illustrates the findings seen between group 1-A and 1-B (solid lines, as shown in Fig. 1), and compares the findings in subgroup 2-A (tube fed without EGF) and subgroup 2-D (tube fed with anti-IgG EGF). There was no difference between any of the points in the tube-fed pups (TF . no EGF or TF + antiEGF) and MF + EGF, except in the rate of glucose uptake. This is reflected by an increase in $V_{\max }$ (Table 1) in the MF + EGF compared to all the formula-fed pups. The MF . control (group 1-A) showed significant decrease in glucose uptake from 5-30 mM glucose from all the other pups ( $p$ $<0.02$ ). Not shown are the data from the tube-fed pups receiving EGF added to the milk (subgroup 2-B). Data from this group were not different from the other tube-fed pups.

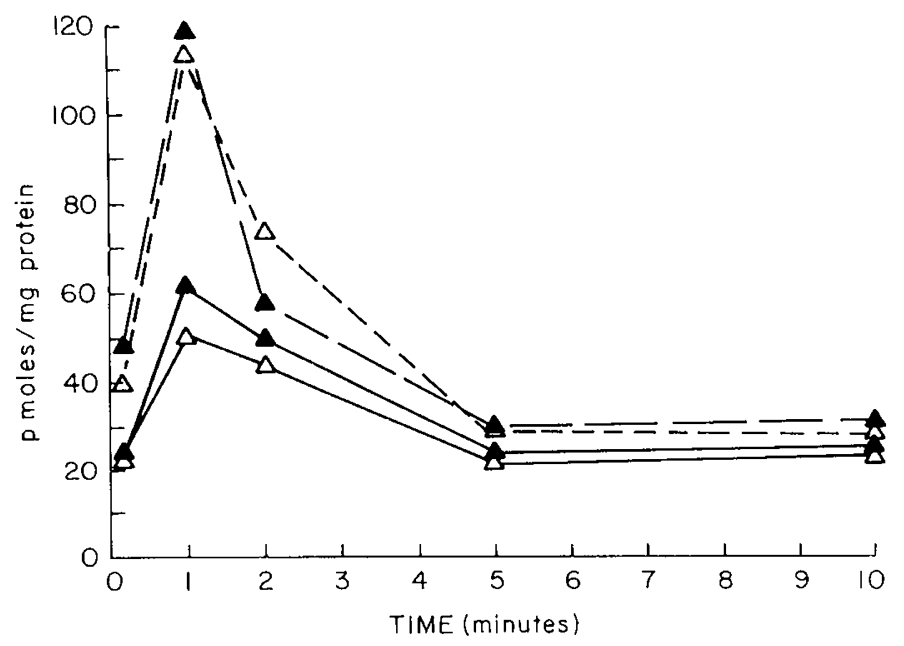

Fig. 3. Results of glucose uptake in BBMV as a function of time. There was a significant difference $(p<0.02)$ in uptake at $1 \mathrm{~min}$ (the "overshoot") between tube-fed pups receiving $200 \mathrm{ng} / \mathrm{ml}$ EGF (solid triangles, broken line) and the tube-fed pups without EGF (solid triangles, solid line). There was no difference between any of the points between the mother-fed pups receiving subcutaneous injections of $0.1 \mu \mathrm{g} / \mathrm{g}$ body weight EGF (open triangles, broken line) and those receiving $200 \mathrm{ng} / \mathrm{ml}$ of oral EGF, nor was there any difference between the mother-fed pups not receiving EGF (open triangles, solid line) and the tube-fed pups not receiving EGF.

Glucose uptake from gut sheets. Glucose uptake in the motherfed rat pups injected with EGF expressed as a function of glucose concentration was lower than that in control animals at concentrations of 1 and $2 \mathrm{mM}$ glucose, but greater at concentrations above $10 \mathrm{mM}$ (Fig. 1). There were no significant differences in glucose uptake among any of the three groups of artificially fed rat pups (Fig. 2), nor were there any significant differences between any one of the artificially fed groups and the EGFtreated mother-fed group.

Both the $\mathrm{V}_{\max }$ and the $\mathrm{K}_{\mathrm{m}}$ were significantly increased in the mother-fed EGF-treated pups as compared to all other groups (Table 1). However, only the $\mathrm{V}_{\max }$ was significantly increased in the artificially fed pups. The group of pups (subgroup 2-C) who received the pharmacologic dose of EGF $(200 \mathrm{ng} / \mathrm{ml})$ added to the formula did not have glucose measurements performed by the gut sheet technique.

Glucose transport in brush border membranes. The transient accumulation of D-glucose at the 1-min "overshoot" (second data point, Fig. 3) was significantly increased in the mother-fed EGF-treated and the artificially fed pups that received the pharmacologic oral dose of EGF. Equilibrium values at 5 and $10 \mathrm{~min}$ were similar for all groups. Glucose uptake in artificially fed pups that received a physiologic dose $(65 \mathrm{ng} / \mathrm{ml})$ of oral EGF was identical to that of group 1-B and group 2-A (data not shown).

\section{DISCUSSION}

Several investigations have demonstrated trophic effects of EGF on developing intestine $(2-5,31,32)$, and the presence of EGF in human milk has been suggested to be of substantial importance in intestinal development $(6,32-34)$. To test the hypothesis that EGF in milk plays an important role in the ontogeny of the intestine during the first several days of life, we developed an EGF-deficient formula and gave it as the sole source of nutrition to a group of 3-day-old suckling rat pups for a period of 8 days.

We anticipated that the EGF-deficient formula would result in poor intestinal growth and decreased rate of glucose transport as compared to pups who were normally suckled or pups fed an EGF-containing, but otherwise identical, formula. In contrast to what we anticipated, all pups fed the artificial milk, with or without added EGF, showed increased intestinal growth and enhanced glucose uptake compared to the normally suckled pups. In fact, the degree of enhanced intestinal growth and glucose uptake was similar to that observed when normally suckled pups received a pharmacologic dose of EGF parenterally. The exception was that, whereas the pharmacologic dose of EGF caused an increase in both $\mathrm{K}_{\mathrm{m}}$ and $\mathrm{V}_{\max }$ for glucose uptake, tube feeding the formula resulted only in an increased $V_{\text {max }}$. This suggests that both the affinity for the glucose transporter and the activity or number of glucose transporters were altered by parenteral EGF administration. On the other hand, the affinity for the carrier was not altered by tube feeding. In support of this is the finding that a pharmacologic oral dose of EGF caused an 
increase in the magnitude of "overshoot" in glucose uptake by BBMV, suggesting an increase in the number of glucose transporters.

Based on these initial findings, we postulated either that the EGF in maternal milk was not required to increase intestinal growth and glucose transport or that the stress of tube feeding results in increased endogenous production of EGF or other factors capable of stimulating intestinal growth and maturation. Urinary excretion of EGF was not affected by tube feeding or the addition of physiologic doses of EGF to the formula. Although urinary excretion appears to be simply a reflection of renal EGF production and not related to blood levels, it tends to support the contention that the accelerated rate of glucose transport was not secondary to a generalized stimulation in EGF output.

In an effort to answer this question, antibodies that reacted with rat EGF were given both in the formula and by parenteral injection to pups fed the EGF-deficient artificial formula. This treatment had no demonstrable effect on either intestinal growth, urinary EGF excretion, or glucose transport kinetics compared to pups fed the artificial formula alone, suggesting that endogenous EGF was not required for the effects observed in artificially fed pups. However, we cannot be certain that the EGF antibody actually neutralized the effect of EGF in vivo. For example, EGFanti-EGF complexes like other antigen-antibody complexes, are known to disassociate in acid $\mathrm{pH}$ in vitro (35). Thus, the orally administered anti-EGF may not have effectively neutralized EGF secreted into the gastrointestinal tract of the pups by the salivary, gastric, or duodenal glands. It is also possible that parenterally administered anti-EGF may not reach the epithelium of the gastrointestinal lumen in sufficient concentrations to exert a neutralizing effect. In support of these possible limitations on the neutralizing effect of administered anti-EGF, we found no change in urinary EGF and that precocious eye opening and tooth eruption, characteristics classically attributed to EGF action, occurred to an equal degree in all the pups given the artificial formula (13).

Thus, our studies could not identify a physiologic role for EGF in milk during ontogeny of intestinal glucose transport. Feeding rat pups from days 3 to 11 with artificial formula without EGF served as a potent stimulus for intestinal growth and glucose transport, but the mechanism by which it elicited this response is unknown. As it is currently constituted, our model does not appear to be capable of resolving this question.

Hoath (36) has shown that maximum response to EGF in terms of somatic, hepatic, and renal growth occurs during the first 3 days of life. Therefore, it may be necessary to initiate studies at the time of birth although EGF in milk is only onetenth of that by day 5 of lactation. Alternatively, agents that specifically impair endogenous EGF production or action would be extremely useful in further investigations into the physiologic role of EGF during development.

Acknowledgments. The authors thank Charles D. Mount and Patty Vieira for excellent technical assistance.

\section{REFERENCES}

1. Cohen S 1962 Isolation of a mouse submaxillary gland protein accelerating incisor eruption and eyelid opening in the newborn animal. $\mathrm{J}$ Biol Chem 237:1555-1562

2. Carpenter G, Cohen S 1979 Epidermal growth factor. Ann Rev Biochem 48:193-216

3. Beaulicu JF, Calvert R 1981 The effect of epidermal growth factor (EGF) on differentiation of the rough endoplasmic reticulum in fetal mouse small intestine in organ culture. J Histochem Cytochem 29:765-770

4. Malo C, Menard D 1982 Influence of epidermal growth factor on the development of suckling mouse intestinal mucosa. Gastroenterology 83:23 -35
5. Oka Y, Ghishan FK, Greene HL, Orth DN 1983 Effect of mouse epidermal growth factor/urogastrone on the functional maturation of rat intestine Endocrinology 112:940-944

6. Moran JR, Courtney ME, Orth DN, Vaughn R, Greene HL 1983 Epidermal growth factor in human milk: daily production and diurnal variation during early lactation in mothers delivering at term and premature gestation. $J$ Pediatr 103:402-405

7. Read LC, Francis GL, Wallace JC, Ballard FJ 1985 Growth factor concentrations and growth-promoting activity and human milk following premature birth. J Dev Physiol 7:135-145

8. Forgue-Lafitte ME, Laburthe M, Chambilier MC, Moody AJ, Rosselin G 1980 Demonstration of specific receptors for EGF-urogastrone in isolated rat intestinal epithelial cells. FEBS Lett 114:243-246

9. Cohen S, Carpenter G 1975 Human epidermal growth factor: Isolation and chemical and biological properties. Proc Natl Acad Sci USA 72:1317-1321

10. Savage CR Jr, Inagami T, Cohen S 1972 The primary structure of epidermal growth factor. J Biol Chem 247:7612-7619

11. Dymsza HA, Czajka DM, Miller SA 1964 Influence of artificial diet on weight gain and body composition of the neonatal rat. J Nutr 84:100-106

12. Messer M, Thoman EB, Terrasa AG, Dallman RP 1969 Artificial feeding of infant rats by continuous gastric infusion. J Nutr 98:404-410

13. Moore MC, Greene HL, Said HM, Ghishan FK, Orth DN 1986 Effect of cpidermai growth factor (EGF) and artificial feeding in suckling rats. Pediatr Res 20:1248-1251

14. Anderson TA, Raffety CJ, Birkhofer KK, Fomon SJ 1980 Effect of feeding frequency on growth and body composition of gastrostomized rat pups. J Nutr 110:2375-2380

15. Savage CR Jr, Cohen S 1972 Epidermal growth factor and a new derivative: rapid isolation procedures and biological and chemical characterization. J Biol Chem 247:7609-7611

16. Hirata X, Orth DN 1979 Epidermal growth factor (urogastrone) in human fluids: size heterogeneity. J Clin Endocrinol Metab 48:673-679

17. Hirata Y, Orth DN 1979 Conversion of high molecular weight human epidermal growth factor (hEGF)/urogastrone (UG) to small molecular weight $\mathrm{hEGF/UG}$ by mouse EGF-associated arginine esterase. J Clin Endocrinol Metabol 49:481-483

18. Moore JB Jr 1978 Purification and partial characterization of epidermal growth factor isolated from the male rat submaxillary gland. Arch Biochem Biophys 189:1-7

19. Simpson RJ, Smith JA, Moritz RL, O'Hare MJ, Rudland PS, Morrison JR, Lloyd CJ, Grego B, Burgess AW, Nice EC 1986 Rat epidermal growth factor: complete amino acid sequence. Eur J Biochem 153:629-637

20. Vaitukaitis JL 1981 Production of antisera with small doses of immunogen: Multiple intradermal injections. Methods Enzymol 73:46-52

21. Starkey RH, Orth DN 1977 Radioimmunoassay of human epidermal growth factor (urogastrone). J Clin Endocrinology Metab 45:1144-1153

22. Mount CD, Lucas TJ, Orth DN 1985 Purification and characterization of epidermal growth factor ( $\beta$-urogastrone) and epidermal growth factor fragments from large volumes of human urine. Arch Biochem Biophys 240:3342

23. Cuatrecasas $P 1970$ Protein purification by affinity chromatography: derivatizations of agarose and polyacrylamide beads. J Biol Chem 245:3059-3065

24. Batt AE, Schachter D 1969 Developmental pattern of some intestinal transport mechanisms in newborn rats and mice. Am J Physiol 216:1064-1068

25. Said HM, Greene HL, Moore GC, Ghishan FK 1987 Developmental maturation of $\mathrm{D}$-glucose active transport system in rat intestine. Digestion (in press)

26. Karasov WH, Diamond JR 1983 A simple method for measuring intestinal solute uptake in vitro. J Compar Physiol 152:105-116

27. Kobayashi Y, Mandsley DV 1979 Practical aspects of double isotope counting. In: Bransome E, Grune S (eds) Liquid Scintillation Counting. Grune and Stratton, Inc., New York, pp 76-85

28. Evers C, Haase W, Murer H, Kinne R 1978 Properties of brush border vesicles isolated from rat kidney cortex by calcium precipitation. Membrane Biochem 1:203-209

29. Ghishan FK, Wilson FA 1985 Developmental maturation of D-glucose transport by rat jejunal brush border membrane vesicles. Am J Physiol 248:G87G92

30. Vaughn WK, Neal RA, Anderson AJ 1976 Computer estimation of the parameter of the sigmoidal and kinetic model. Compt Biol Med 6:1-7

31. Malo C, Menard D 1982 Influence of epidermal growth factor on the development of suckling mouse intestinal mucosa. Gastroenterology 82:28-32

32. Thornbury W, Matrisian L, Magun B, Koldovsky O 1984 Gastrointestinal absorption of epidermal growth factor in suckling rats. Am $\mathrm{J}$ Physiol 246:G80-G85

33. Carpenter $G 1980$ Epidermal growth factor is a major growth-promoting factor in human milk. Science 210:198-200

34. Koldovsky O 1980 Hormones in milk. Life Sci 26:1833-1836

35. Porath J, Christiansen T 1975 Biospecific affinity chromatography and related methods. In: Neurath H, Hill R (eds) The Proteins, Academic Press, New York, pp 95-178

36. Hoath SB 1986 Treatment of the neonatal rat with epidermal growth factor. Differences in time and organ response. Pediatr Res 20:468-472 